\title{
THE CENTRALIZATION OF CAPITAL IN THE PROPERTY SECTOR AND THE RESTRUCTURING OF METROPOLITAN AREAS
}

\author{
centralização do capital no setor imobiliário e reconfiguração das metrópoles
}

Daniel Sanfelici *

\begin{abstract}
Resumo
Na esteira das transformações recentes nos negócios imobiliários no Brasil, muitas pesquisas abordaram as repercussões econômicas e socioespaciais da formação de grandes grupos empresariais com abrangência nacional. Na discussão sobre as forças econômicas que viabilizaram a expansão de um grupo pequeno de incorporadoras, é recorrente (embora implícito) o entendimento de que o caráter tardio do processo de centralização do capital nos negócios imobiliários decorreria do poder das elites regionais de preservarem para si o segmento imobiliário como órbita exclusiva de valorização de seus capitais. Embora reconhecendo que o argumento possa ter validade parcial, pretende-se, aqui, argumentar que o ingresso tardio dos negócios imobiliários na dinâmica de formação de grupos econômicos nacionais decorre, prioritariamente, do caráter singular da mercadoria imóvel, que impõe uma série de obstáculos à centralização do capital no setor. $\mathrm{O}$ artigo organiza-se em três partes. Inicialmente, oferecemos alguns apontamentos teóricos em torno do conceito de centralização do capital. Em seguida, na segunda seção, discutimos as circunstâncias econômicas que diferenciam o processo de centralização no setor imobiliário. Por fim, refletimos sobre a relevância do conceito de centralização do capital para pensar as mudanças urbanas recentes.
\end{abstract}

Palavras-chave: Centralização do capital; Financeirização; Mercado Imobiliário; Reestruturação urbana.

\begin{abstract}
IFollowing the recent changes in Brazil's real estate industry, many researches have focused on the economic and socio-spatial effects of the appearence of large, nationally-operating business groups. In discussing the economic forces behind this expansion of a small group of developers, it is common (though implicit) the understanding that the centralization of capital was delayed in this sector due to regional elites' capacity to preserve the property sector as an exclusive field for the operation of their capitals. While recognizing that the argument may be partially valid, we argue that the late development of large property business groups results, primarily, from the unique character of property as a commodity, which creates obstacles to the centralization of capital in the real estate sector. The paper is divided into three sections. Initially, we offer a few theoretical signposts around the concept of centralization of capital. Then, in the second part, we discuss the economic circumstances that differentiate the centralization of capital in the real estate sector. Finally, we consider the relevance of the concept of centralization to deal with recent changes in urban areas.
\end{abstract}

Key words: Centralization of capital; Financialization; Real estate market; Urban restructuring.

\section{Resumen}

En vista de las transformaciones recientes ocurridas en los negocios inmobiliarios en Brasil, muchas investigaciones han abordado las repercusiones económicas y socioespaciales de la formación de grandes grupos empresariales de alcance nacional. En la discusión sobre las fuerzas económicas que viabilizaron la expansión de un grupo pequeño de promotoras inmobiliarias, es recurrente (aunque implícito) el entendimiento de que el carácter tardío del proceso de centralización del capital en los negocios inmobiliarios resultaría del poder de las élites regionales de preservar para sí el segmento inmobiliario como órbita exclusiva de valorización de sus capitales. Aun reconociendo que el argumento pueda ser parcialmente válido, se pretende argumentar aquí que el ingreso tardío de los negocios inmobiliarios en la dinámica de formación de grupos económicos nacionales resulta, prioritariamente, del carácter singular de la mercadería inmueble, que impone una serie de obstáculos a la centralización del capital en el sector. El artículo se organiza en tres partes. Inicialmente, ofrecemos algunos apuntes teóricos sobre el concepto de centralización del capital. A continuación, en la segunda sección, discutimos las circunstancias económicas que diferencian el proceso de centralización en el sector inmobiliario. Por último, reflexionamos sobre la relevancia del concepto de centralización del capital para pensar los cambios urbanos recientes.

Palabras clave: Centralización del capital; Financierización; Mercado Inmobiliario; Reestructuración urbana.

(*) Lecturer, Doctor of the Federal University Fluminense - Campus da Praia Vermelha, Boa Viagem - Niterói (RJ), Brasil. Tel: (+55 21) 26295951 - danielsanfelici@gmail.com 


\section{INTRODUCTION}

The economic processes behind metropolitan development in Brazil have dramatically changed since the beginning of the 21 st century. The close relationship tying capital markets together, increasingly open to foreign investments since the last decade, and private housing development and building have infused the restructuring of urban spaces with a rhythm and dynamism never seen before, thus redefining Brazil's urbanization process. At the heart of this process is the real estate sector, which until recently consisted of small, regional, family-owned firms, but is now increasingly controlled by a limited but powerful group of large-scale developers that raised capital in the stock exchange to fund a strategy of geographical dispersal. Even in cases where families retained control over their firms, these organizations are now structured differently, especially due to their need to meet shareholders' expectations of higher profitability.

In this paper, we aim to discuss the nature of these economic changes by turning our attention to the centralization of capital in Brazil's real estate sector. In many critical accounts of the urban dynamics, real estate has been viewed both as a sector that generates exorbitant profits - mainly as a result of the close ties between entrepreneurs and local governments - and as a business activity that underpins the power and economic reproduction of regional oligarchic elites. This is due to the latter's ability to set up barriers to external competitors within its territory and thus to extract monopoly rents by seizing urban real estate. While we recognize the partial validity of these arguments, in this paper, we intend to look into the particularities of the centralization of capital in the real estate sector. As we will see, such particularities strongly distinguish the real estate sector from other economic sectors, inasmuch as they forge distinctive relationships between scales of capital accumulation. We will argue that these scalar particularities have preserved, up until recently, the real estate sector as a field of investment virtually exclusive to local groups and families. This is not so much due to these groups' ability to impose monopoly barriers on external competitors, but instead to the nature of the geographical dynamics of the real estate business.

This distinct geographical dynamic can be observed when we examine the recent changes caused by the sector's increasing financialization. Firms' access to equity finance through capital markets has favored capital centralization through mergers and acquisitions, giving rise to a select group of firms operating at the national scale. This group of corporate developers has placed regional, family-controlled developers under increasing competitive pressure. However, for reasons we will explain throughout the article, the appearance of these nationally-organized groups does not wipe out small regional firms, as the latter are able to take advantage of unique assets to stay in the market. The centralization of capital thus takes on a distinctive form in the real estate sector, not necessarily giving rise to oligopolistic competition, and these singularities affect the spatial organization of metropolitan areas. Following brief theoretical observations on the notion of centralization of capital, we then examine, in the second section, the evolution of this process in Brazil's real estate sector. Finally, in the third part, we discuss the socio-spatial effects of this process.

\section{CENTRALIZATION OF CAPITAL: PRELIMINARY THEORETICAL REMARKS}

We begin with some preliminary theoretical remarks that are potentially useful for the discussion that follows. The centralization of capital appears in Marx's work in close connection to the idea of concentration of capital. The latter refers to the steady concentration of means of production in autonomous units of capital valorization, as a result of the incessant reinvestment of surplus value (capital accumulation) induced by the "external coercive laws" of competition. It is worth underscoring that what defines the individuality of capital (and therefore the concentration of capital) is not its physical materiality (plants and means of production), but instead its unity "over a circulation flow whose form is that of a circular process of changes in the form of value" (AGLIETTA, 2000, p. 216). Concentration thus refers not (necessarily) to the physical growth of production units, 
but instead to the growing "control over a process of valorization" (AGLIETTA, 2000) in which the economic and judicial boundaries that separate one capital from another are preserved. This is why, according to Marx, concentration occurs when "the growth of social capital occurs through the growth of numerous individual capitals" (MARX, 1981, p. 776).

As opposed to concentration, which perpetuates the autonomy of capital units, centralization is the result of the "forces of attraction" (MARX, 1980) that unfold over the course of capital accumulation. It qualitatively reshapes the field of accumulation insofar as it redraws the boundaries previously set between individual capitals either through the absorption of certain firms by another or through the merger between two or more firms. However, in contrast to concentration, which is a continuous (though uneven) process, centralization of capital tends to occur in waves of mergers and acquisitions followed by phases of relative inactivity (growth via simple concentration).

According to Michel Aglietta (2000), such surges in mergers and acquisitions likely occur at two points over the course of the business cycles that typically define capital accumulation: (1) at the end of a period of stagnation when a systematic devaluation of capital takes place, a condition that favors an improvement in profit rates due to declining organic compositions of capital; and (2) at the end of a long period of capital formation, when rates of surplus value turn downward, indicating the onset of a phase of economic turbulence.

The association of these waves of mergers and acquisitions with specific phases of the business cycle suggests that the centralization of capital performs a necessary function in the accumulation process. It is tied to the appearance of a set of pressures and constraints that stem from the competition among capitals in phases of accelerated change in the business environment. Examples abound here: a rise in prices for raw materials used in a given sector may encourage firms to associate in order to drive down such prices through economies of scale in purchase; fiercer price competition may spur mergers between capitals that together are in a better position to adopt more technologically-intensive methods of production; trade liberalization or foreign investment in a country could force firms to take defensive measures that lead to consolidation, just to cite a few.

Marx acknowledges the importance of such market constraints when he notes that centralization appears as a key solution to speed up accumulation whenever individual capitals are unable to attain a threshold quantity required to operate in sectors where technical and operational conditions demand a larger amount of investment (Marx frequently cited railways as an example). It would be a mistake, however, to treat centralization as a purely technical or commercial phenomenon. Insofar as centralization entails a reorganization of ownership and, therefore, a redistribution of the rights to appropriate future labor, it is often accompanied by high-risk speculative gambles through which capitalists aim to defend or improve their positions with respect to one or more circuits of valorization. The intensity with which capitalists join such speculative ventures and the form these ventures take depend, however, on the institutional and regulatory design of the credit system and on the political structure prevalent in a given historical context. Credit is, inevitably, a cornerstone in the creation of new business groups through mergers and acquisitions, and those that are able use it to their own benefit stand to gain in the overall distribution of surplus value. As Marx asserts in his chapter on the general law of capitalist accumulation, in the first volume of "Capital",

[...] the battle of competition is fought by cheapening of commodities. The cheapness of commodities depends, ceteris paribus, on the productiveness of labour, and this again on the scale of production. Therefore, the larger capitals beat the smaller. [...] Apart from this, with capitalist production an altogether new force comes into play: the credit system, which in its first stages furtively creeps in as the humble assistant of accumulation, drawing into the hands of individual or associated capitalists, by invisible threads, the money resources which lie scattered, over the surface of society, in larger or smaller amounts; but it soon becomes a new and terrible weapon in the battle of competition and is finally transformed into an enormous social mechanism for the centralisation of capitals (MARX, 2013, p. 702). 
There is, though, a wide range of possible configurations in the intermediary role played by credit in the centralization process: in the US, for instance, the preeminence of capital markets and non-bank financial institutions (investment funds and institutional investors) within the credit system has given rise, since the 1980s, to a market for controlling firms in which business groups are bought out and restructured (through layouts and management overhauls) with a view to short-term capital gains (BRAGA, 1997; CINTRA, 2000). Contrastingly, in Brazil, the historically low levels of domestic savings and the shortage of long-term credit has given the state a crucial role in industrial reorganization and conglomeration (COUTINHO; BELLUZZO, 1982; TAVARES; MIRANDA, 1999). In this context, the influence exerted by private interest groups over political decisions has always been a privileged route to appropriating a larger share of the surplus product (FIORI, 2003).

There is another aspect of centralization that closely relates to the discussion carried out in the subsequent sections: the fact that centralization often entails a geographical dimension (SMITH, 2008). To put it differently, the process of the social centralization of capital is historically associated with a tendency towards the spatial agglomeration of capitals in privileged hubs of economic activity, generating an inter-regional division of labour in which the most competitive regions polarize the valorization of capital. This spatial dimension of centralization needs to be taken into account in order to grasp its specificities in the case of the real estate sector.

It has been widely known since Marx that one of the inherent characteristics of capitalism refers to capital's relentless need to remove time and space barriers that hinder its expanded reproduction. Over the course of its growth, capital inevitably generates surpluses that cannot be profitably reabsorbed within its own investment field (HARVEY, 1999; 2003). Finding new markets that can provide a profitable outlet for such surpluses is thus essential to capital. This is why capitalism is characterized by endless technological improvements in communications and transport, a trend that leads, on the one hand, to a steady broadening of the geographical arena of capital accumulation and, on the other, to shortening turnover times.

The integration of geographical space through the diffusion (and cheapening) of transportation and communication infrastructures produces a "scalar jump" (SMITH, 1993) in capitalist markets, because it puts into direct competition economic agents whose regional markets had been previously protected by the monopolistic advantages conferred by the "friction of distance" (HARVEY, 1989; 1999); in other words, the high costs involved in shipping commodities to distant markets, which made long-distance trade impractical to most businesses. However, the creation of a unified space of valorization, that historically found expression in the integration of national markets, is not a spontaneous and conflict-free process. Insofar as it involves breaking the (relative) autonomy of regional spaces and unsettling the class alliances that gave this space its coherence and stability, the integration of capitalist space encounters several obstacles that can only be overcome through political means (BRANDÃO, 2007).

What deserves to be underscored here is that, once a national market takes shape as a unified space of capital valorization, the centralization of capital gathers momentum and its spatial dimension becomes clearer (SMITH, 2008). The integration of markets tends to wipe out those capitals whose levels of productivity prove insufficient within a new environment of intercapitalist competition. These are often businesses that operated in regions where market relations were thin or embryonic. At the same time, businesses based in regions where market relations were thicker not only saw a rise in their speed of capital accumulation, but also sought to associate with one another to enjoy economies of scale and thus supply the national market with lower prices. The spatial integration of capitalism thus favors a centralization of social capital that is, at the same time, a geographical concentration of capitals in a few privileged nodes within the national territory, and these nodes end up commanding the territorial division of labor. This tendency toward territorial polarization as an inevitable consequence of spatial integration is clearly exemplified by the case of São Paulo, in Brazil, which concentrated, at its peak in 1980, almost $60 \%$ of the country's industrial output, 
effectively subjecting capital accumulation in other regions to its own economic performance (BRANDÃO, 2007; CANO, 2011).

While the history of manufacturing clearly demonstrates the close connection between territorial integration and (social and spatial) centralization of capital, the same cannot be said about the real estate sector. In fact, as Mariana Fix (2011) noted, the real estate sector has remained, for a long stretch of history in Brazil, a sphere of valorization under almost exclusive control of the local elite whose influence over political and administrative decisions guaranteed handsome profits in urban property investments. At issue here, though, is whether this monopolization of a business sector by the local elite stems from this group's ability to block the access of competitors into their region of influence so as to enjoy monopoly profits or, alternatively, whether the real estate sector itself functions in a way that poses obstacles to the centralization of capital in a way similar to the manufacturing sector. The answer cannot, evidently, be reduced to a binary choice: both explanations may be partially true, depending on the concrete case being analyzed. However, many studies that have examined the evolution of the real estate sector in Brazil have put (perhaps unreasonable) emphasis on the first explanation and have rarely considered the second. Without neglecting the effort and capacity of the local elite to insulate their markets from external competition - as the historical dispute between regional elites within Brazil's state administration demonstrates - we argue here that the main explanation for the fact that, until recently, the real estate sector had remained a predominantly local sector comes from technical and economic particularities that sharply distinguish this sector from the manufacturing sector. These particularities also explain the distinctive nature of the centralization process that followed the public listing of major developers in Brazil's stock exchange, a process that was analyzed recently by a few scholars (SHIMBO, 2010; MARTINS, 2010; FIX, 2011; SANFELICI, 2013a).

\section{THE DISTINCTIVE NATURE OF CAPITAL CENTRALIZATION IN THE REAL ESTATE SECTOR}

What are the characteristics of the real estate sector that make it less prone to a centralization of capital along the lines of major manufacturing sectors, which results in oligopolistic competition? Three basic features of property as a commodity and of the real estate market as a field of accumulation distinguish the prevalent forms of competition in the sector and create barriers to the establishment of national corporate groups: (1) the fixity of property on land; (2) the low homogeneity of property; (3) few barriers of entry to new competitors.

The first of these obstacles is relatively self-evident: as opposed to most sectors of manufacturing, in which a single plant located anywhere in the territory is capable of supplying the entire domestic market, the commodity produced by the real estate sector is fixed on land. This means that the production process has to be carried out in the same place of its end consumption, thus giving this sector some features comparable to the service sector (BUZZELLI; HARRIS, 2006). This imperative hardly changes with subcontracting, which theoretically would allow a firm to easily enter a new regional market without incurring heavy upfront costs. Negotiations over land purchase, the conception of a project that conforms to the land plot's location and to the particularities of local demand, the bureaucratic procedures for project approval with local authorities (including environmental impact assessment in the case of larger projects), the supervision of contracts with suppliers and subcontractors, among others, are all factors that put a premium on proximity, thus forcing firms to set up regional branches with knowledgeable professional teams.

The main consequence of this necessity is that, in order to enter a distant market, firms must calculate the viability of such a strategy comparing the added costs of setting up operational, managing and in some cases production facilities in the new city with the expected profits that it may accrue in this new market. Such a decision may lead to different strategies, as seen in the expansion of large developers in Brazil between 2005 and 2010 (SHIMBO, 2010; FIX, 2011; SANFELICI, 
2013a). Some developers chose to retain control of the construction process and, to do so, they transferred to new markets not only technical and managing personnel, but also entire segments of the production process (such as plants for producing precast concrete and other inputs). The major problem with this strategy is that it requires a minimum scale of operation that is only justified in larger markets. In other words, the additional costs of setting up business in a new region, and transferring to it the operational and technical conditions for increasing revenues have to be largely offset by a certain level of housing output, which can only be achieved, in Brazil, in large urban agglomerations.

This path toward regional expansion is illustrated by Rossi Residential and its move into the state of Rio Grande do Sul, in Southern Brazil (SANFELICI, 2013a). Originally based in São Paulo, the firm adopted a long-term policy aimed at increasing market share in Rio Grande do Sul. This state eventually made up a large share of Rossi's overall housing output in Brazil. Rossi's growing market share, obtained through the launching of ambitious and highly visible developments, as well as through marketing campaigns, led managers to open up a factory of precast concrete in the municipality of Canoas, on the outskirts of the state capital Porto Alegre. This factory now supplies inputs to all of Rossi's developments in the metropolitan area of Porto Alegre.

The second strategy for entering new markets relies on contracting out most of the building process to a regional partner, who then executes the projects according to the technical specifications (size, use of materials, finishing, etc.) of the larger firm. A wide range of contract types can seal these partnerships, resulting in different functions and amounts of work for the agents involved. As a rule, though, these partnerships reduce the outlay needed for entering a new market, making it possible for developers to build in less populous areas or where demand is limited.

This strategy for expansion became dominant in Brazil over the past few years, because it favored developers' quick dispersion to smaller cities. Under pressure from shareholders to increase output, developers saw in these partnerships a way of attaining their ambitious goals. The use of partnerships ran up against some serious difficulties, though: local builders often lacked the technical, managing and operational expertise to build at the pace, quality and cost-margin expected by larger corporate developers. These mounting difficulties squeezed developers' profitability in some regions, forcing some of them to break up these partnerships and retreat to more dynamic and established markets (the Southeast and South). This demonstrates that, despite helping firms skirt some obstacles in gaining access to new markets, partnerships pose several latent risks related to the insufficient knowledge about local partners and to the management of joint projects.

The second characteristic refers to the unique nature of property as a use value, which makes determining its exact exchange value particularly problematic. This specificity stems from the fact, noted by Henri Lefebvre (2000, p. 391), that those who buy a house are buying not just an inhabitable volume, easily interchangeable with any other house of the same size and construction quality. Additionally, the buyer obtains a "distance: the one that separates one's home from other places, [such as] commercial, work, leisure, cultural and decision centers" (LEFEBVRE, 2000, p. 391). To put it differently, an inherent and crucial aspect of property as a commodity is its location with regard to the whole urban agglomeration, of which it is part. This location grants the buyer a qualitatively different, and in some ways unique access to the economic and social advantages generated by spatial proximity. Additionally, although property is fixed on land, its location is variable when seen from the standpoint of relative space (HARVEY, 1999; 2006): investments in transportation and communication, so long as they transform the spatial relations that underpin social reproduction, redefine a land lot's position in relation to the urban region.

Insofar as the price of property includes, in the form of capitalized land rent, its position in relative space, two houses that are identical in technical and architectural terms may still be (and 
commonly are) very different from one another, leading to widely divergent prices. The comparison with certain sectors of manufacturing is instructive here: while a car with certain technical specifications is identical whether it is bought in Manaus or in São Paulo, two houses with identical specifications, but one located in Jardins, São Paulo's high-end district, and the other on the outskirts of Manaus, are completely different commodities. As long as one of the central motives of housing development consists of appropriating land rent by converting a land plot to a more profitable use, it is indispensable for developers to acquire an in-depth knowledge of the local trends of spatial restructuring. This specialized knowledge is what makes it possible for developers to design housing projects that are successful in terms of appropriating land rent.

In addition to gaining in-depth knowledge about the spatial dynamics of local real estate markets, developers who aim to venture into a new market need to place themselves in tangled networks of business relationships tying together a variety of public and private agents in the market - from landowners to subcontractors, architects, lawyers, planners, etc. Taking part in these networks which amounts, after all, to a long learning process - is an indispensable precondition for a firm to succeed in a given market (BALL, 1983; BUZZELLI; HARRIS, 2006). In this context, acquiring a regional firm takes on a different meaning (besides the previously mentioned one of reducing the costs of entering a new market): the key asset that developers seek when buying or establishing partnerships with small family-controlled builders is precisely this kind of specialized knowledge, built up by local firms through years of experience in the market, about the trends, forces and agents that shape the local real estate market - what Scott \& Storper (2003) called "relational assets". It is only when in possession of this kind of knowledge that large developers may expect to offer housing projects fit for seizing the opportunities for private gain that arise out of economic and population growth in urban areas. However, since securing such knowledge requires buying out or setting up joint ventures with poorly known local firms, the aforementioned risk is posed anew.

The third factor that makes the centralization of capital a unique phenomenon in the real estate sector refers to the barriers to entry (and exit) in this market. In contrast to those segments of manufacturing in which a high content of fixed capital erects a barrier to new competitors, in real estate such barriers are limited. A small amount of money is enough for an entrepreneur to set up a business and put his capital in circulation by building a few small developments, such as houses and small buildings. This is why the real estate sector serves so well the purpose of recycling capital accumulated by local capitalists in other sectors, such as services and retail - a feature that can be easily confirmed by looking at the history of many housebuilding firms, founded by entrepreneurs from other business sectors.

The emergence of large-scale, national developers does not change this scenario much. Small and medium-sized developers not only continue to crop up regularly as entrepreneurs shift capital from other sectors into real estate or, alternatively, as high-income individuals invest their savings in small construction firms, but those developers that had long operated in this sector do not necessarily go bankrupt as larger, better-capitalized firms move into the market. One of the reasons for this is that scale economies in housing development and construction are fairly limited. Additionally, small firms often enjoy certain competitive advantages in relation to publicly-listed companies, such as the ease of hiring informal labor and dodging taxes, their greater knowledge of local markets and the good reputation that comes from an image of craft-based construction methods as opposed to the massified industrial construction of corporate developers (BOURDIEU, 2005).

The atomized structure of capitalist competition within the real estate sector can be seen with the statistical data collected by the Brazilian Institute of Geography and Statistics (IBGE), summed up in Table 1 below. The table shows a clear dominance of small firms (5 to 29 employees), which together make up $73 \%$ of the firms in the building sector, while the top three categories in number of employees make up less than $10 \%$ of the total number of firms. When we look at the right column, which shows the number of employees, the distribution among different categories of firms 
is more balanced, with larger firms employing the largest number of employees (27\%). Still, the proportion of employees working in smaller firms is fairly significant (18\%).

Table 1 - Firms in the housebuilding sector in Brazil - 2011

\begin{tabular}{c|c|c|c|c}
\hline Firms by number of employees & Number of firms & $\mathbf{\%}$ & Number of employees & $\mathbf{\%}$ \\
\hline From 5 to 29 & 15,741 & $73 \%$ & 169,285 & $18 \%$ \\
\hline From 30 to 49 & 1,792 & $8 \%$ & 69,164 & $7 \%$ \\
\hline From 50 to 99 & 1,967 & $9 \%$ & 137,063 & $14 \%$ \\
\hline From 100 to 249 & 1,298 & $6 \%$ & 197,284 & $20 \%$ \\
\hline From 250 to 499 & 387 & $2 \%$ & 132,103 & $14 \%$ \\
\hline More than 500 & 239 & $1 \%$ & 257,961 & $27 \%$ \\
\hline Total & $\mathbf{2 1 , 4 2 4}$ & $\mathbf{1 0 0} \%$ & $\mathbf{9 6 2 , 8 5 9}$ & $\mathbf{1 0 0 \%}$ \\
\hline
\end{tabular}

Source: Pesquisa Anual da Construção Civil 2011 (IBGE).

This atomization is thus a regular feature of the real estate sector, even, in the case of Brazil, after a group of firms was listed in the stock exchange. In fact, even when we analyze data concerning the amount of expenditures by firms, which could broadly be used as a proxy for market share, we can see that the two top categories (from 250 to 499 and over 500 employees) add up to approximately $40 \%$ of the expenditures. This conclusion is consistent with other studies of the real estate sector after large, nationally-integrated developers emerged, such as that of Michael Ball (1983) for the United Kingdom and Buzelli \& Harris (2006) for Canada and the US.

These three basic features of property as a use value and of real estate as an economic sector - the fixity of property on land, its weak homogeneity as a commodity and the limited barriers to entering the sector - gives the process of centralization a different economic meaning than it has in sectors prone to oligopolistic consolidation. On the one hand, there are considerable (and persistent) barriers to the centralization of capital through the formation of national corporate groups, stemming from the fact that, in order to grow beyond a certain size, firms have to shift production processes and management structures to new regions. This shift brings with it, as we have seen, a range of risks and uncertainties that can slow down or even frustrate expansion plans. On the other hand, due to the few barriers for entering the real estate sector, even when some larger firms prevail in terms of units produced, total built area and added value, there remain opportunities for the reinvestment of capital originating in other economic sectors or in households savings. These economic groups and households find in real estate an opportunity to preserve and expand their accumulated wealth.

In view of the above, it seems fitting to suggest that the persistence of real estate as a privileged outlet for reinvesting surplus capital by the regional elite has little to do with the latter's ability to impose monopoly barriers to external investment flowing from other regions. It also has little to do with a presumed propensity for rentism by the regional elite, who would rather extract unproductive land rent to reproduce and expand their wealth than invest in activities that create more jobs and increase productivity. While these explanations may prove correct in some cases, it is worth drawing attention to the distinctive context and economic dynamics of the real estate sector that hinder the centralization of capital in the way it occurred in manufacturing sectors. That is what makes real estate a sector that is particularly amenable to the investment of locally-accumulated surplus capitals.

Could we, then, conclude that the centralization of capital in real estate has little effect on metropolitan spaces? In other words, if the real estate market functions as an outlet for the valorization of the capital of small family businesses who, relying on unique assets, compete on equal terms with publicly-listed corporate developers, should we then conclude that the centralization of capital has an insignificant impact on the urban spatial configuration? An adequate answer to this 
question demands an understanding of how large corporate developers operate in the production of urban space, and the recent restructuring of the sector in Brazil offers a privileged vantage point to observe the strategies of these business groups.

\section{THE PLACE OF LARGE DEVELOPERS IN THE PRODUCTION OF METROPOLITAN SPACES}

Analyzing Brazil's recent economic scenario is a fruitful path towards clarifying the urban impacts of the centralization of capital in the real estate market. With regard to the recent evolution of this sector in Brazil, it is worth underscoring the exceptional growth rate of a small number of developers. Figure 1, below, shows seven firms that regularly appear in the list of top ten developers in Brazil. We can see a sharp rise in the number of housing units launched by these developers: starting from an insignificant number in 2005, the combined output of this group exceeded the mark of 180,000 units in 2010. As was suggested above, these data indicate a profound organizational restructuring, especially given that, up to 2005, these firms were mostly local or regional concerns whose administration was strictly controlled by the founders' families.

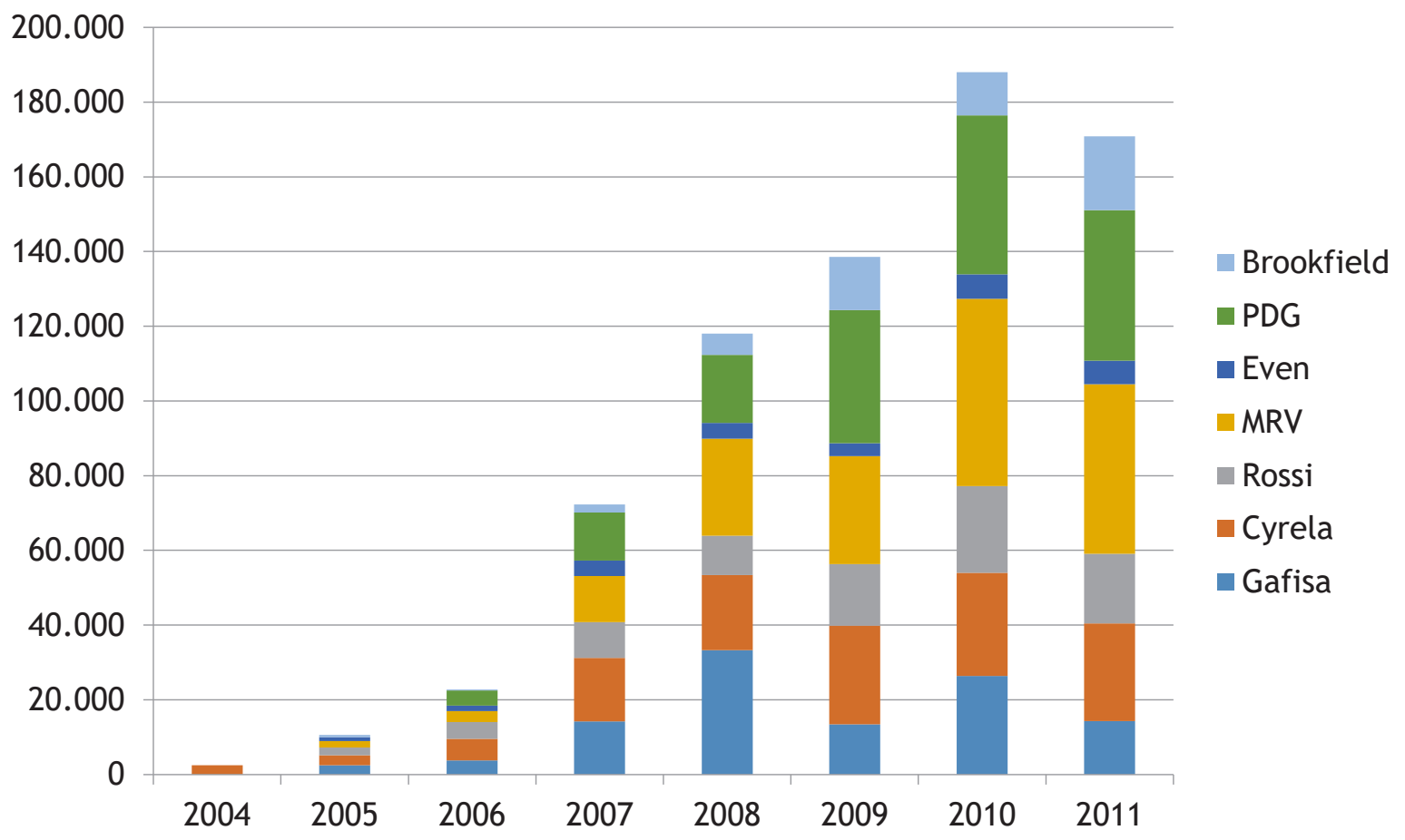

Figure 1 - Number of units launched by seven large developers in Brazil Source: Firms' annual reports.

More than just a quantitative change in annual launchings and sales, the recent centralization of capital in Brazil's real estate sector signals qualitative changes that need to be taken into account in order to understand the production of metropolitan spaces today. It should be noted that the concentration and centralization of capital in the real estate sector took place under the auspices of a financial capital that is not the same as that which had marked previous phases of capitalist accumulation. Especially important in understanding the nature of capitalist finance today is to consider the growing prominence of investment funds and institutional investors pooling scattered surplus money and seeking investment opportunities in an increasingly unified economic space (BRAGA, 1997; CHESNAIS, 2002; CINTRA, 2000; GUTTMANN, 2008; BELLUZZO, 2013). Such agents and their intermediaries give priority to assets that combine higher returns with liquidity, thus allowing the adoption of a risk management strategy centered on the possibility of reassessing, in real time, the composition of their portfolios. In addition, as shareholders of large corporate groups, these investors often display activist behavior towards managers, demanding generous dividend 
distributions or, alternatively, short-term corporate restructurings that potentially favor the appreciation of the firm's stocks and bonds in the secondary market.

These were the agents that acquired stakes in Brazil's housing developers through the stock market, leveraging them to scour profit opportunities wherever they may be. Under constant evaluation and strong pressure from shareholders to deliver results, large developers pursued aggressive strategies to generate revenue, opening up new fields of accumulation through a diversification policy that took three key directions: regional (expanding to peripheral markets outside São Paulo); social (targeting other income strata, especially following the increasing availability of mortgage credit); and segment (new products, such as corporate offices, suburban developments, etc.). The construction of increasingly larger housing developments was also a key means through which these firms raised their outputs and profitability in order to satisfy their shareholders' expectations (SANFELICI, 2013a).

The impact of these developers on urban space, as well as their differences with regard to a wide range of small, family-controlled developers that persist in this market, is better understood when we closely examine this new environment of increasing shareholder pressure on firms' strategic decisions. Real estate activity is predicated upon the private appropriation of rent increases originating in the continuous reconfigurations of the city's centralities. A vital aspect of the real estate business thus consists of diagnosing the key tendencies, forces and directions of metropolitan spatial restructuring so as to change land uses in ways that maximize the appropriation of the rents that such urban transformations bring about. The profits earned are thus predicated upon the private appropriation of potential land rent generated by the changed spatial position of a site in relation to the whole urban agglomeration. We are not ignoring here that a significant share of the profits that developers accrue originate in surpluses generated in the construction itself, especially when a developer is also a builder. What is meant instead is that, in the housing development business, the construction process is subordinate to strategic decisions that depend on an acute spatial sensitivity. It is about taking advantage of the new economic frontiers that urban development constantly produces.

The key advantage and distinguishing feature of corporate developers (leveraged by capital markets) in relation to smaller developers lies in their ability to create entirely new urban frontiers by raising large amounts of capital in financial markets, instead of passively taking advantage of the economic opportunities that arise out of the decentralized actions of numerous private and public agents. The tendency towards large-scale housing developments became a reality after a group of developers raised equity in the stock market in 2005-7 (RUFINO, 2012; SANFELICI, 2013a). Its impact on cities can be seen in the growing number of large luxury condominiums on the outskirts of cities, "planned developments" combining condominiums, entertainment and retail facilities on a single site, as well as multifunctional projects blending residential and office space. While these large-scale projects used to be exclusive to Brazil's economic hubs (São Paulo and Rio de Janeiro), they have recently spread across major urban agglomerations (including non-metropolitan ones).

Less clear, at least at first sight, is the fact that the frontiers opened up by corporate developers' mega-projects reshape the field of accumulation in the real estate market insofar as they transform the land-rent surface that is the foundation of developers' activities. In other words, by creating new centralities of real estate wealth that polarize and reconfigure the metropolitan structure, large developers also alter the opportunities for profit available to smaller developers. The latter often end up (though not inevitably) performing a more passive role of following the economic opportunities created by larger developers that, relying on elaborate marketing campaigns, are able to channel demand in certain (often unexpected) directions of the city, as opposed others.

These frontiers of valorization led by corporate developers (and by the financial investors as their shareholders) are further enhanced when aided by forms of public intervention that give precedence to the "global side" of cities with a view to improving their competitiveness in an environment of 
volatile capital mobility. Additionally, many such interventions demand an amount of investment that can only be mobilized by large-scale corporate developers. This is the case, for instance, of São Paulo's so-called urban operations (CARLOS, 2001; FIX, 2007), which have targeted the city's business districts through the sale of construction rights to private developers (permissions for land use intensification beyond the limits set by the city's master plan). The minimum scale required to make investments viable in such business districts strongly favors large corporate developers, who additionally see these policies as a safeguard for the valorization of their capital due to the public sector's commitment to applying the funds raised by selling construction rights in the targeted area. This explains why large corporate developers and other real estate businesses with ties to capital markets, such as real estate investment trusts and property companies managing shopping malls, are dominant in these areas.

A second effect of the centralization of capital, especially in the way it occurred in Brazil through developers' ties with capital markets, refers to the real estate market's increasing susceptibility to internalizing the volatility of financial markets. In this context, it is worth underscoring that housebuilding has always displayed a growth pattern marked by stronger cyclical fluctuations than is the case in other sectors. This has to do with the long turnover times of capital invested in real estate development (BALL, 2003), a characteristic that the sector shares with other sectors producing capital equipment. The cyclical dynamic is explained here by the fact that, when demand for housing increases, developers cannot supply new housing units in a short period of time, thus causing prices to rise. As prices go up, positive expectations in the market induce developers to overinvest, which causes, after some years of growth, oversupply and an ensuing decline in housing prices.

This cyclical dynamic tends to be sharper the more the real estate market is open to the circulation of finance capital (HARVEY, 2012). For this reason, the creation of a market for property-backed securities, a measure that has been at the center of the reformulation of housing finance systems in most capitalist economies over the last three decades (ROLNIK, 2013), reinforces the volatility of real estate investment inasmuch as it makes the sector prone to cyclical fluctuations typical of financial asset markets. The formation of optimistic conventions, founded on unrealistic expectations about the future returns of property-backed financial assets, encourages capital to flow into the sector and helps inflate asset bubbles. These bubbles end up bursting sooner or later, leaving behind a legacy of balance-sheet imbalances and empty properties with a strong negative impact on cities, as the subprime crisis in the US clearly demonstrated (NEWMAN, 2009; DYMSKI, 2010; HARVEY, 2012).

The relatively recent integration of the stock market and the real estate sector in Brazil could suggest, at first sight, that this dynamic does not apply to this country. On the one hand, it is true that one should avoid transposing dynamics and processes typical of advanced economies to Brazil. On the other, however, acknowledging the fact that financialization advanced more consistently on the supply side through the relationship established between developers and shareholders, recent research has shown that large corporate developers have acted as key transmission chains for the speculative dynamics that emanate from financial markets (FIX, 2011; SANFELICI, 2013a). This becomes clear when we observe the behavior of some firms after raising equity and debt in stock markets: following these firms' initial public offerings (IPOs), the stock market began to assess firms' future profitability on the basis of their land banks. Housing developers' land banks thus started to underpin their valuation in the stock market. In this context, firms frantically scrambled to buy up urban land across the country, in an attempt to advertise their potential for growth to shareholders. This growth-oriented strategy had clear consequences for metropolitan areas in Brazil, especially after the rise in prices beginning in 2009: the rising price of land pushed lower-income development projects further to the outskirts of cities, thus reinforcing a sprawled pattern of urbanization with high social and environmental costs. 
As noted above, the centralization of capital faces substantially greater barriers in the real estate sector than in other sectors. Additionally, the particularities of this sector give rise to a market structure in which small firms make up a considerable share of the firms operating in the sector. However, we should not conclude from this that the centralization of capital does not take place in this sector, nor that it has irrelevant outcomes for cities. The two processes identified in this article - the ability of corporate developers to spawn new frontiers of development in urban space with large-scale projects and these firms' tendency to embrace strategies that echo the speculative dynamics of financial markets - signal some paths for diagnosing and theorizing about the impacts of the centralization of capital in the real estate sector on urban and regional spaces. However, more research is needed in order to improve our understanding of centralization effects on cities, especially considering that developers' access to the stock market is still a relatively recent phenomenon in Brazil.

\section{FINAL CONSIDERATIONS}

Over the past ten years, Brazilian cities have seen the multiplication of large-scale real estate developments that have profoundly reshaped their landscapes. Though this growth is partly a consequence of the improved performance of the Brazilian economy between 2005 and 2012, we cannot grasp the speed and depth of these changes without bringing into focus the drive towards the centralization of capital in real estate, strongly pushed by large investment funds. However, when assessing this process in the case of real estate, it is vital to consider this sector's specificities and its roots in the singularity of property as a commodity. As discussed throughout this article, these specificities raise obstacles to the formation of nationwide corporate groups, and these obstacles arise out of informational asymmetries that create difficulties for these firms' activities in distant markets. For this reason, the internationalization of real estate activities in Brazil hinges on an unstable and contradictory arrangement of accumulation scales. Not so much an eccentricity of a supposedly backward sector, the belated formation of large corporate business groups in the real estate sector is explained, primarily, by the economic circumstances that make this sector and its dynamic of reproduction so peculiar.

\section{BIBLIOGRAPHIC REFERENCE}

AGLIETTA, Michel. A theory of capitalist regulation: the US experience. New York: Verso, 2000.

BALL, Michael. Housing and economic power: the political economy of owner occupation. London: Methuen, 1983.

BALL, Michael. Markets and the structure of the housebuilding industry: an international perspective. Urban Studies, 40(5-6), p. 897-916, 2005.

BELLUZZO, Luiz Gonzaga; COUTINHO, Luciano. O desenvolvimento do capitalismo avançado e a reorganização da economia mundial no pós guerra. In: BELLUZZO, Luiz Gonzaga; COUTINHO, Renata (orgs.). Desenvolvimento capitalista no Brasil: ensaios sobre a crise. São Paulo: Brasiliense, 1982.

BELLUZZO, Luiz Gonzaga. O capital e suas metamorfoses. São Paulo: Editora Unesp, 2013.

BOURDIEU, Pierre. The social structures of the economy. Cambridge: Polity, 2005.

BRAGA, José Carlos. Financeirização global: o padrão sistêmico de riqueza do capitalismo contemporâneo. In: FIORI, José Luis; TAVARES, Maria da Conceição (orgs). Poder e dinheiro: uma economia política da globalização. Petrópolis: Vozes, 1997.

BRANDÃO, Carlos. Território e desenvolvimento: as múltiplas escalas entre o local e o global. Campinas: Editora da Unicamp, 2007.

BUZZELLI, Michael; HARRIS, Richard. Cities as the industrial districts of housebuilding. International Journal of Urban and Regional Research, 30(4), p. 894-917, 2006. 
CANO, Wilson. Novas determinações sobre as questões regional e urbana após 1980. Revista Brasileira de Estudos Urbanos e Regionais, 13(2), 27-53, 2012.

CARLOS, Ana Fani Alessandri. Espaço-tempo na metrópole: a fragmentação da vida cotidiana. São Paulo: Editora Contexto, 2001.

CHESNAIS, François. A teoria do regime de acumulação financeirizado: conteúdo, alcance e interrogações. Economia e Sociedade, 11(1), p. 1-44, 2002.

CINTRA, Marcos Antônio Macedo. A dinâmica do novo regime monetário-financeiro americano: uma hipótese de interpretação. Revista Estudos Avançados, (39), p. 103-141, 2002.

DYMSKI, Gary. Why the subprime crisis is different: a Minskyian approach. Cambridge Journal of Economics, 34(2), p. 239-255, 2010.

FIORI, José Luis. O vôo da coruja: para reler o desenvolvimentismo brasileiro. Rio de Janeiro: Editora Record, 2003.

FIX, Mariana. Financeirização e transformações recentes no circuito imobiliário no Brasil. Campinas: IE/Unicamp, 2011 (Tese de Doutorado).

GUTTMANN, Robert. Uma introdução ao capitalismo dirigido pelas finanças. Novos estudos CEBRAP, (82), p. 11-33, 2008.

HARVEY, David. The urban experience. Oxford: Blackwell, 1989.

HARVEY, David. The limits to capital. New York: Verso, 1999.

HARVEY, David.The new imperialism. Oxford: Oxford University Press, 2003.

HARVEY, David. Spaces of global capitalism. New York: Verso, 2006.

HARVEY, David. Rebel cities: from the right to the city to the urban revolution. New York: Verso, 2012.

LEFEBVRE, Henri. La production de l'espace. Paris: Anthropos, 2000.

MARX, Karl. Capital: a critique of political economy (3 vol.). New York: Penguin, 1981.

MARX, Karl. O capital - Vol 1. São Paulo: Boitempo, 2013.

MARTINS, Flávia Elaine da Silva. A (re)produção social da escala metropolitana: um estudo sobre a abertura de capitais nas incorporadoras e sobre o endividamento imobiliário urbano em São Paulo. São Paulo: FFLCH/USP, 2010 (Tese de Doutorado)

MIRANDA, José Carlos; TAVARES, Maria da Conceição. Brasil: estratégias de conglomeração. In: FIORI, José Luís (org.). Estados e moedas no desenvolvimento das nações. Petrópolis: Vozes, 1999.

NEWMAN, Kathe. Post-industrial widgets: capital flows and the production of the urban. International Journal of Urban and Regional Research, 33(2), p. 314-331, 2009.

ROLNIK, Raquel. Late neoliberalism: the financialization of homeownership and housing rights. International Journal of Urban and Regional Research, 37(3), p. 1058-1066, 2013.

RUFINO, Maria Beatriz Cruz. A incorporação da metrópole: centralização do capital no imobiliário e nova produção de espaço em Fortaleza. São Paulo: FAUUSP, 2012 (Tese de Doutorado).

SANFELICI, Daniel. A metrópole sob o ritmo das finanças: implicações socioespaciais da expansão imobiliária no Brasil. São Paulo: FFLCH/USP, 2013a (Tese de Doutorado).

SANFELICI, Daniel. A financeirização do circuito imobiliário como rearranjo escalar do processo de urbanização. Confins (Paris), v. 18, p. 1-16, 2013 b.

SANFELICI, Daniel; HALBERT, Ludovic. Financial markets, developers and the geographies of housing in Brazil: A supply-side account. Urban Studies, 0042098015590981, 2015.

SCOTT, Allen J; STORPER, Michael. Regions, globalization, development. Regional studies, 41(S1), p. 191-205, 2006.

SHIMBO, Lúcia Zanin. Habitação Social, Habitação de Mercado: a confluência entre Estado, empresas construtoras e capital financeiro. São Carlos: Escola de Engenharia de São Carlos, 2010 (Tese de Doutorado). SMITH, Neil. Contours of a spatialized politics: homeless vehicles and the production of geographical scale. Social Text, (33), p. 55-81, 1992.

SMITH, Neil. The new urban frontier: Gentrification and the revanchist city. New York: Routledge, 1996. 
SMITH, Neil. Gentrificação, a fronteira e a reestruturação do espaço urbano. GEOUSP: espaço e tempo, (21), p. 15-31, 2007.

SMITH, Neil. Uneven development: Nature, capital, and the production of space. Atlanta: University of Georgia Press, 2008.

Submitted february 2016

Accepted march 2016 
The Centralization of Capital in the Property Sector and the Restructuring of Metropolitan Areas 